\title{
Conceptualising the demand for ecosystem services - an adapted spatial-structural approach
}

\author{
Claudia Dworczyk $k^{\ddagger}$, Benjamin Burkhard ${ }^{\ddagger}, \S$ \\ ‡ Leibniz Universität Hannover, Hannover, Germany \\ $\S$ Leibniz Centre for Agricultural Landscape Research ZALF, Müncheberg, Germany
}

Corresponding author: Claudia Dworczyk (dworczyk@phygeo.uni-hannover.de)

Academic editor: Alessandra La Notte

Received: 15 Mar 2021 | Accepted: 30 Oct 2021 | Published: 07 Dec 2021

Citation: Dworczyk C, Burkhard B (2021) Conceptualising the demand for ecosystem services - an adapted spatial-structural approach. One Ecosystem 6: e65966. https://doi.org/10.3897/oneeco.6.e65966

\begin{abstract}
People require multiple ecosystem services (ES) to meet their basic needs and improve or maintain their quality of life. In order to meet these needs, natural resources are exploited, threatening biodiversity and increasing the pressure on the Earth's ecosystems.
\end{abstract}

Spatial-structural approaches are used to explain and visualise the spatial relationships and connections between areas that provide and benefit from ES. However, areas where the demand for these ES occurs are rarely considered in existing spatial approaches or equated with areas where people can use the benefits.

In order to highlight the differences between these two areas, we would like to introduce the 'Service Demanding Area' (SDA) in an adapted spatial-structural approach.

This approach relates SDA to already familiar ES provision and use units, namely Service Providing Areas (SPA), Service Connecting Areas (SCA) and Service Benefitting Areas (SBA) and can be used to schematically illustrate, understand and analyse the different forms of demand that can emerge.

A literature review was conducted to provide an overview of the spatial mapping of ES demand. Three issues arose that should be addressed to improve the assessment of ES demand: 1) The term ES demand is not used consistently. To avoid confusion, it is important to clarify how ES demand is understood and how it differs from the other 
components of the ES concept (e.g. ES supply, ES potential, ES flow); 2) It is important to consider that ES demand is multi-faceted and is generated on different geographical scales, including the full range of stakeholders' perceptions, needs and desires which broadens the picture of societal demand for ES; 3) Meaningful interpretations between ES supply and demand need to be available to inform decision-makers about interventions for reducing ES trade-offs and mismatches.

\section{Keywords}

service providing area; service benefitting area; service demanding area; service connecting area

\section{Introduction}

Biodiversity and healthy ecosystems are essential to support and sustain human well-being (IPBES 2019). People require multiple ecosystem services (ES) to meet their basic needs and to improve or to maintain their quality of life. To meet these needs, ecosystems are exploited to satisfy the increasing demand for drinking water, food, materials, energy and other wishes (Millennium Ecosystem Assessment 2005, Maes et al. 2020, Vysna et al. 2021).

The concept of ES describes the various contributions of ecosystem to human well-being (Maes et al. 2018). It is an anthropocentric concept, as the benefits people obtain from ecosystems are the main focus (Millennium Ecosystem Assessment 2005). These benefits can include any "positive change in well-being through the fulfilment of needs and wants" (Potschin-Young et al. 2018) which refers, not only to products and goods, but also to health improvements, experiences or positive effects that may result from ES.

ES research is becoming increasingly important as the consequences of overuse of resources, climate change, biodiversity loss and other environmental changes become more tangible (IPBES 2019). The ES concept has already achieved policy relevance in recent years and has the potential to become an important tool for decision-makers in (environmental) policy, spatial planning and economy, as it can address linkages between environmental, social and economic issues (Maes et al. 2018, Maes et al. 2020). It provides a holistic framework for examining: 1) the extent to which people need or demand ES to meet their basic needs and to improve their quality of life and 2) the extent to which nature can meet those in a sustainable way (Burkhard and Maes 2017, Wolff et al. 2017).

The ES concept is embedded in national ecosystem assessments, which are driven by the Convention on Biological Diversity (CBD) (European Union 2011, Secretariat of the Convention on Biological Diversity 2020), assessments of the Intergovernmental Platform on Biodiversity and Ecosystem Services (IPBES) (IPBES 2019) or natural capital accounting (The Economics of Ecosystems and Biodiversity (TEEB) 2010, United Nations 2021). Recently, the UN System of Environmental-Economic Accounting (SEEA) presented 
a "statistical framework for organizing biophysical information about ecosystems, measuring ecosystem services, tracking changes in ecosystem extent and condition, valuing ecosystem services and assets and linking this information to measures of economic and human activity" (United Nations 2021). This framework is consistent with the national accounting standards (United Nations 2021).

Even though the ES concept has gained increasing importance in scientific research, research gaps continue to reduce its practical application (Heckwolf et al. 2020, Czúcz et al. 2020, Grunewald et al. 2021). There are a number of open conceptual and methodological questions that remain to be addressed, in particular, on the subject of ES demand (Wolff et al. 2015, Geijzendorffer and Roche 2014, Geijzendorffer et al. 2015). For example, ES literature often emphasises that ES demand is very multifaceted, as it is driven by various factors, including, for example, access to ES, socio-economic conditions, demographic changes, technological influences and marketing (Villamagna et al. 2013, Wolff et al. 2017, Schröter et al. 2018). However, this diversity makes it difficult to understand and to map ES demand (Wolff et al. 2015, Czúcz et al. 2020). Using schematic illustrations and examples, this article presents the different ways in which demand for ES can be spatially allocated. It aims to show how spatial distribution of ES supply and demand is ES-dependent and how the spatial dynamics of ES flows play a crucial role in understanding the actual fulfilment of ES demand and the spatial allocation of benefits. For this purpose, we have developed the concept of a Service Demanding Area (SDA), which we have integrated into the existing spatial-structural approaches.

Before discussing the SDA in detail, we will summarise our understanding of key ES terms and provide a brief overview of existing concepts used to describe the application of ES components in spatial-structural contexts. We will then look at the literature on ES demand, focusing on those papers which deal with the development of an adapted spatial-structural approach, before introducing the SDA. Above all, the following discussion will seek to synthesise key findings on assessing and mapping ES demand in a spatial-structural context, while also proposing, in the form of the SDA, a new element with which to further develop the ES approach.

\subsection{Definitions of ES key terms with specific focus on ES demand}

The inter- and transdisciplinary nature of the ES concept has led to the development of different understandings of the ES terminologies (Bastian et al. 2012, Honey-Rosés and Pendleton 2013).

In the European Union, the initiative Mapping and Assessment of Ecosystems and their Services (MAES) synthesises knowledge about ES and aims to improve the evidence base for sustainable policy developments in the context of the EU Biodiversity Strategies 2020 and 2030 (European Union 2011). MAES brings together research results from many scientific fields, making a common understanding of the ES concept essential. Therefore, a comprehensive MAES glossary was created, bringing together the various existing definitions. The glossary was also expanded with terms that reflect, not only ES-research, but also specific topics (Potschin-Young et al. 2018). It should be noted that these 
harmonised definitions have an explicit focus towards the research topic of mapping and assessing ES. In developing the spatial-structural approach, we mainly followed the MAES understanding (Potschin-Young et al. 2018) of the key terms of ES supply, ES potential, ES flow and ES demand, which are listed in Table 1 and explained in more detail below.

The distribution of ES tends to be spatially heterogeneous and can change over time. ES are generated by ecological processes and functions, which, in turn, are influenced by biodiversity, local climates, topography, land cover, human activities and land-use decisions (Wei et al. 2017, Schirpke et al. 2019b). This provision of ES by specific ecosystems, irrespective of their actual use, has commonly been referred to as ES supply (Burkhard et al. 2012, Potschin-Young et al. 2018, Vallecillo et al. 2019, González-García et al. 2020).

In the ES concept, the consideration of ES potential is important. Here, the potential (or hypothetical) quantities or qualities of ES that can be provided or used in a certain region are examined in light of current land use and ecosystem conditions and properties (Burkhard and Maes 2017, Maes et al. 2020). ES potential can be used to show: (a) the extent to which an ecosystem can potentially provide services and (b) what limitations there are likely to be on the sustainable and/or permanent use of these services (PotschinYoung et al. 2018).

ES flow describes "the amount of an ecosystem service that is actually mobilised in a specific area and time" (Potschin-Young et al. 2018, p. 23). Matter, energy and/or information can be exchanged between ecosystems in ways from which people can benefit (Kleemann et al. 2020). This exchange can, depending on the nature of the specific ES, take place within a localised surrounding or over long distances, for example, through trade, transport, political decisions or ecological phenomena, such as global climate regulation (Schröter et al. 2018). Here, the focus is on ES which are delivered or accessed either passively, via biophysical processes (e.g. airflow) or actively, as a result of human involvement (i.e. via water pipelines, through food transport etc.) (Ala-Hulkko et al. 2019). Individual actors can also play an important role in the ES flow dynamics by enabling or restricting the transport and access of ES in the first place (La Notte and Dalmazzone 2018). This has implications for where and which people can actually benefit from the respective ES.

ES demand can be described as "the need for specific ecosystem services by society, particular stakeholder groups or individuals. It depends on several factors such as culturally-dependent desires and needs, availability of alternatives, or means to fulfil these needs. It also covers preferences for specific attributes of an ecosystem service and relates to risk awareness" (Potschin-Young et al. 2018, p. 20). The needs or wishes for ES vary from people to people as well as from situation to situation. The needs depend on many factors, for example, the availability of natural resources, socio-cultural backgrounds and the (financial) ability to meet these needs (Maslow 1954). Since the underlying reasons are manifold, they can also be expressed in different ways. Wolff et al. (2015) suggested to use different types of demand rationale. ES demand can be expressed and assessed as: (1) an expression of wishes, values and norms; (2) derived from the different 
forms of use and/or (3) consumption of ES and (4) or as the need for risk reduction/ prevention and increased security (Wolff et al. 2015). The form of expression, therefore, depends on what the assessor wants to emphasise, be it dependence on functioning (local) ecosystems, the benefits acquired from these or the different preferences and patterns of use within a society (Wolff et al. 2017). The location of demand for some ES produces additional challenges. This is particularly the case for ES that pursue environmental goals on a global scale (e.g. global climate regulation or the conservation of natural habitats) and whose benefits are reaped worldwide or are strongly shaped by inherent moral (or intrinsic) values (Burkhard et al. 2012, Jax et al. 2013, Baró et al. 2015, Sauter et al. 2019).

Table 1.

Table 1 shows how important key terms are defined or explained: a) in the Oxford Dictionary (Oxford University Press (OUP) 2020); b) in the core glossary of ecosystem services mapping and assessment terminology (Potschin-Young et al. 2018) and c) defintions or explanations in official reports on ecosystem accounting from the United Nations (United Nations 2019, United Nations 2021).

\begin{tabular}{|c|c|c|c|}
\hline & $\begin{array}{l}\text { Main meaning (with } \\
\text { relation to the ES } \\
\text { concept) in the } \\
\text { Oxford Dictionary } \\
\text { (Oxford University } \\
\text { Press (OUP) 2020) }\end{array}$ & $\begin{array}{l}\text { Definitions in the core glossary of } \\
\text { ecosystem services mapping and } \\
\text { assessment terminology (Potschin- } \\
\text { Young et al. 2018) }\end{array}$ & $\begin{array}{l}\text { Definitions or explanations in } \\
\text { official reports on ecosystem } \\
\text { accounting from the United } \\
\text { Nations (United Nations } 2019 \text {, } \\
\text { United Nations 2021). }\end{array}$ \\
\hline Capacity & $\begin{array}{l}\text { 1) The maximum } \\
\text { amount that something } \\
\text { can contain. } \\
\text { 2) The amount that } \\
\text { something can } \\
\text { produce. }\end{array}$ & $\begin{array}{l}\text { Capacity (for an ecosystem service): } \\
\text { "The ability of a given ecosystem to } \\
\text { generate a specific ecosystem service in } \\
\text { a sustainable way" (p. 12). }\end{array}$ & $\begin{array}{l}\text { "Ecosystem capacity is the ability of } \\
\text { an ecosystem to generate an } \\
\text { ecosystem service under current } \\
\text { ecosystem condition, management } \\
\text { and uses, at the highest yield or use } \\
\text { level that does not negatively affect } \\
\text { the future supply of the same or } \\
\text { other ecosystem services from that } \\
\text { ecosystem" (p. 335) (United Nations } \\
\text { 2021). }\end{array}$ \\
\hline Demand & $\begin{array}{l}\text { 1) An insistent and } \\
\text { peremptory request, } \\
\text { made as of right. } \\
\text { 1. a) Pressing } \\
\text { requirements (usually } \\
\text { demands). } \\
\text { 1. b) The desire of } \\
\text { consumers, clients, } \\
\text { employers etc. for a } \\
\text { particular commodity, } \\
\text { service or other item. }\end{array}$ & $\begin{array}{l}\text { Demand (for an ecosystem service): } \\
\text { "The need for specific ecosystem } \\
\text { services by society, particular } \\
\text { stakeholder groups or individuals. It } \\
\text { depends on several factors, such as } \\
\text { culturally-dependent desires and needs, } \\
\text { availability of alternatives, or means to } \\
\text { fulfil these needs. It also covers } \\
\text { preferences for specific attributes of an } \\
\text { ecosystem service and relates to risk } \\
\text { awareness" (p. 20). }\end{array}$ & No definition. \\
\hline
\end{tabular}




\begin{tabular}{|c|c|c|c|}
\hline & $\begin{array}{l}\text { Main meaning (with } \\
\text { relation to the ES } \\
\text { concept) in the } \\
\text { Oxford Dictionary } \\
\text { (Oxford University } \\
\text { Press (OUP) 2020) }\end{array}$ & $\begin{array}{l}\text { Definitions in the core glossary of } \\
\text { ecosystem services mapping and } \\
\text { assessment terminology (Potschin- } \\
\text { Young et al. 2018) }\end{array}$ & $\begin{array}{l}\text { Definitions or explanations in } \\
\text { official reports on ecosystem } \\
\text { accounting from the United } \\
\text { Nations (United Nations } 2019 \text {, } \\
\text { United Nations 2021). }\end{array}$ \\
\hline Flow & $\begin{array}{l}\text { 1) The action or fact of } \\
\text { moving along in a } \\
\text { steady, continuous } \\
\text { stream. } \\
\text { 1.a) The rate or speed } \\
\text { at which something } \\
\text { flows. } \\
\text { 1.b) The rise of a tide } \\
\text { or a river. } \\
\text { 2) A steady, continuous } \\
\text { stream or supply of } \\
\text { something. }\end{array}$ & $\begin{array}{l}\text { Flow (of an ecosystem service): "The } \\
\text { amount of an ecosystem service that is } \\
\text { actually mobilised in a specific area and } \\
\text { time" (p. 23). }\end{array}$ & $\begin{array}{l}\text { Explanations for actual flow: } \\
\text { "The ecosystem services supply } \\
\text { and use account records the actual } \\
\text { flows of ecosystem services } \\
\text { supplied by ecosystem types and } \\
\text { used by economic units during an } \\
\text { accounting period" (p. 77). } \\
\text { (United Nations 2019). } \\
\text { "Following standard accounting } \\
\text { treatments, the measure of the } \\
\text { supply and use are equivalent and } \\
\text { will be equal to the actual flow } \\
\text { between the ecosystem asset and } \\
\text { people" (p. 117) (United Nations } \\
\text { 2021). }\end{array}$ \\
\hline Potential & $\begin{array}{l}\text { 1) Latent qualities or } \\
\text { abilities that may be } \\
\text { developed and lead to } \\
\text { future success or } \\
\text { usefulness. } \\
\text { 1.a) The possibility of } \\
\text { something happening } \\
\text { or of someone doing } \\
\text { something in the future } \\
\text { (often potential for/to } \\
\text { do something). } \\
\text { As an adjective: } \\
\text { 2) Having or showing } \\
\text { the capacity to develop } \\
\text { into something in the } \\
\text { future. }\end{array}$ & $\begin{array}{l}\text { Ecosystem service potential: } \\
\text { "The natural contributions to ecosystem } \\
\text { service generation. It measures the } \\
\text { amount of ecosystem service that can } \\
\text { be provided or used in a sustainable } \\
\text { way in a certain region. This potential } \\
\text { should be assessed over a sufficiently } \\
\text { long period of time" (p. 21). }\end{array}$ & $\begin{array}{l}\text { The potential supply of ES } \\
\text { "indicating the potential sustainable } \\
\text { flow of services, assuming that } \\
\text { there is no limitations in the demand } \\
\text { for the service" (p. 21) (United } \\
\text { Nations 2019). }\end{array}$ \\
\hline Supply & $\begin{array}{l}\text { 1) A stock or amount of } \\
\text { something supplied or } \\
\text { available for use. } \\
\text { 1.a) The action of } \\
\text { providing what is } \\
\text { needed or wanted. } \\
\text { 1.b) The amount of } \\
\text { goods or service } \\
\text { offered for sale (in } \\
\text { economics). }\end{array}$ & $\begin{array}{l}\text { Ecosystem service supply: "The } \\
\text { provision of a service by a particular } \\
\text { ecosystem, irrespective of its actual use. } \\
\text { It can be determined for a specified } \\
\text { period of time (such as a year) in the } \\
\text { present, past or future" (p. 21). }\end{array}$ & $\begin{array}{l}\text { "Supply of ecosystem services is } \\
\text { equal to the use of those services } \\
\text { during an accounting period, [...], } \\
\text { supply is not recorded if there is no } \\
\text { corresponding use" (p. 77) (United } \\
\text { Nations 2019). }\end{array}$ \\
\hline
\end{tabular}

Unfortunately, all presented terms are not understood or used consistently and there are also further different definitions for the term ES demand (see Table 2 and Suppl. material 1). 
Table 2.

Examples of existing definitions of ES demand used in ES literature. Further definitions, see Suppl. material 1.

\begin{tabular}{|l|l|}
\hline Author & Definition \\
\hline $\begin{array}{l}\text { Burkhard et al. (2012) } \\
\text {, p. } 18\end{array}$ & $\begin{array}{l}\text { "The sum of all ecosystem goods and services currently consumed or used in a particular } \\
\text { area over a given time period not considering where ecosystem services actually are } \\
\text { provided." }\end{array}$ \\
\hline $\begin{array}{l}\text { Villamagna et al. } \\
\text { (2013), p. } 116\end{array}$ & "The amount of a service required or desired by society." \\
\hline $\begin{array}{l}\text { Schröter et al. (2014), } \\
\text { p. 541 }\end{array}$ & $\begin{array}{l}\text { "ES demand is the expression ofthe individual agents' preferences for specific attributes of } \\
\text { the service, such as biophysical characteristics, location and timing of availability and } \\
\text { associated opportunity costs of use". }\end{array}$ \\
\hline $\begin{array}{l}\text { Geijzendorffer et al. } \\
\text { (2015), p. } 322\end{array}$ & $\begin{array}{l}\text { "Demand was defined as the actual expression of the willingness of stakeholders to obtain } \\
\text { a service (for instance, in money, time investments or travel distances)". }\end{array}$ \\
\hline
\end{tabular}

For example, the terms ES supply and ES potential are often used synonymously (Wei et al. 2017, Maes et al. 2020) or are equated with the terms potential ES supply (Goldenberg et al. 2017, Rioux et al. 2019, United Nations 2019) or ES capacity (Burkhard et al. 2009, Geijzendorffer and Roche 2014, González-García et al. 2020).

A few examples underline some of the existing ambiguities between ES flow and ES demand: for example, the definition of Geijzendorffer et al. (2015) is close to the economic understanding of demand. In economics, demand is traditionally understood as the intention and willingness of economic units (e.g. businesses, governments or households) to buy goods, products or services (Bryan et al. 2018).

In SEEA EA, supply and use tables are commonly applied to record the actual flow of ES between ecosystem assets and economic units (United Nations 2019). The SEEA EA follows standard accounting principles, according to which "the measure of the supply and use are equivalent and will be equal to the actual flow between the ecosystem asset and people" (United Nations 2021, p. 117). This means that the actual flow represents the actual use and transaction that takes place between ecosystem types and economic sectors and households (La Notte et al. 2019). However, the actual use of ES does not necessarily consider important spatial aspects. Furthermore, it usually does not take into account broader costs and benefits that may result from increased or decreased consumption of ES that affect other aspects, for example, health. Thus, "ecosystem accounting does not consider the relationship between people and the environment from an economic or social welfare perspective" (United Nations 2019, p. 77). However, current considerations examine experimentally whether the potential flow, as the total flow that the respective ecosystem types can generate for each ES, can also be integrated into the SEEA EA (La Notte and Dalmazzone 2018, La Notte and Marques 2019, La Notte et al. 2019). With this consideration, it would also be possible to examine whether the ecosystems and their services are used in a sustainable way or not (La Notte et al. 2019). 
Demand for ES is often directly associated with the beneficiaries, those (individuals, households or economic units) who perceive the final benefit of the ES. Some studies emphasise that, without the demand for and use of an ES, there is no ES flow (Burkhard and Maes 2017, Czúcz et al. 2020). Therefore, the actual use of ES is often used synonymously as ES flow in the ES mapping literature (e.g. Burkhard et al. 2012, Villamagna et al. 2013, Burkhard et al. 2014, Baró et al. 2015, Zhao and Sander 2015, Baró et al. 2016).

Other ES demand definitions take into account, not only the amount of ES used or consumed, but also the expressed needs, wishes or preferences (Villamagna et al. 2013, Schröter et al. 2014, Potschin-Young et al. 2018). This is an important distinction as expressed needs, desires and preferences for ES may differ from the actual ES received. In this article, we followed this understanding where the demand for ES describes the extent to which society, interest groups or individuals need or desire ES to meet their basic needs and to improve their quality of life.

\subsection{Spatial-structural approaches}

ES mapping approaches have proven to be an essential tool to assess ES and to communicate the complex spatial information of ES (Burkhard and Maes 2017). For comprehensible communication, abstract concepts are often clarified and visualised in an extremely simplified way, not only using maps, but also pictures or illustrations.

In order to be able to describe the differences between the areas where ES are provided and where benefits arise, Fisher et al. (2009) highlighted the spatial relationships between Service Providing Areas (SPA) and Service Benefitting Areas (SBA) in a schematic figure. Syrbe and Walz (2012) extended the scheme to include the Service Connecting Areas (SCA), which give greater consideration to the space between SPA and SBA. As these areas do not necessarily overlap, the location of the SCA can be used to show ES 'flow'. An extended version of these illustrations can be found in Walz et al. (2017).

The spatial dynamics of ES flows can be very diverse. Natural or anthropogenic barriers, sinks or depletions regions have an influence on the distribution and accessibility of ES (Burkhard et al. 2014, Wei et al. 2017). Therefore, ES flows has been the focus in various schematic illustrations that explain, in simple drawings, the spatial dynamics of respective ES (e.g. Serna-Chavez et al. 2014, Rioux et al. 2019). Here, illustrations were on the one side used to explain models. For example, Bagstad et al. (2013) used schematic illustrations to explain the multi-agent simulation system (SPANS) model that focuses on detailed mapping of ES flow. Ala-Hulkko et al. (2019) presented a scheme to explain the calculations in a spatial accessibility analysis, which aims to assess the spatial flows and balance between ES supply and demand. On the other hand, these representations also contribute to increasing the empirical understanding of the spatial dynamics of ES. For example, Syrbe and Grunewald (2017) classified the spatial dynamics of SCA in more 
detail and described six cases, where they included the different scales and various access possibilities:

1. Local: ES are provided and demanded in the same area (in situ). Since the ES do not have to "flow" or be transported as a result, the benefits of these ES can also be located in the same area.

2. Proximity: Natural processes and ecological laws determine the close transfer of ES.

3. Process: Natural processes take place over further distances.

4. Access: People actively access areas to benefit from provided ES.

5. Transport of goods: ES products and goods (wood, food etc.) are transported to people who demand these things.

6. Global: The benefits of some ES are global and cannot be spatially constrained.

The conceptual diagram by Schröter et al. (2018) aims to improve the understanding of inter-regional telecouplings in socio-ecological systems by explaining the spatial dynamics and effects of four different types of inter-regional flows and transport mechanisms between a sending and a receiving system. The authors explained that biophysical ES flows can: a) be transported through human-made carriers (e.g. for food, raw materials); b) take place through species migration and dispersal (e.g. bird migration) and c) arise passively through diverse ecosystem processes and functions (e.g. flood protection). A special point here is that, in the case of cultural ES, the exchange of data, information or media can also represent a form of ES flow. Although the framework focuses on interregional ES flows, the considerations could be applied at any scale (Schröter et al. 2018).

In SEEA EA, tables showing supply and use are applied to record the actual flows of ES between ecosystem assets and economic units (United Nations 2019). There is also an interest in mapping this supply and use information. However, the exchange between ecosystem and economic units takes place from an accounting perspective, which may limit the mapping ambitions. In accounting terms, the ecosystem-economic unit exchange, for example, for provisioning services (food, raw materials) takes place at the point of harvest. This means that ES are treated as provided and used in the same area (in situ). The transport of harvested materials to the regions where it is actually consumed is the subject of standard economic accounting. Therefore, this aspect has no role in ecosystem accounting and is, therefore, not mapped (United Nations 2021).

In these presented approaches, the Service Benefitting Areas equal the areas where people demand ES. This situation, however, is rarely simple. In highly anthropogenicallymodified landscapes, such as cities, some areas have a high demand for ES, such as air quality or local climate regulation, which most cities cannot meet by the few existing remnants of nature (Baró et al. 2015, Grunewald et al. 2021).

This aspect is crucial for detecting ES mismatches, in which the quantity of ES demand exceeds the amount or quality of ES supply (Baró et al. 2015, Geijzendorffer et al. 2015, Syrbe and Grunewald 2017). As ES mismatches can indicate unsustainable use and inequitable distribution, there is an interest in illustrating how, when and where they can 
arise (Villamagna et al. 2013). Looking at two selected ES, Goldenberg et al. (2017), for example, used a schematic illustration to depict the main differences between potential and realised ES supply and demand, emphasising that demand can also remain unmet. We want to further develop these considerations within a spatial context with the integration of the SDA.

\section{Methods}

Based on an examination of available material, existing concepts were summarised and streamlined in order to develop an adapted spatial-structural approach which includes SDA.

\subsection{Literature review}

For the development of our adapted approach, existing reviews and theoretical articles about supply and demand of/for ES were highly relevant (see Fisher et al. 2009, Burkhard et al. 2012, Syrbe and Walz 2012, Villamagna et al. 2013, Geijzendorffer and Roche 2014, Geijzendorffer et al. 2015, Wolff et al. 2015, Hegetschweiler et al. 2017, Stosch et al. 2017, Syrbe and Grunewald 2017, Wei et al. 2017, Walz et al. 2017, Schröter et al. 2018, La Notte et al. 2019). This literature was expanded with further articles by conducting a search in the scientific literature databases, ISI Web of Knowledge (https://webofknowledge.com) and Scopus (http://scopus.com). The search keyword combinations are documented in Table 3. Due to the extensive amount of literature, articles were limited to studies that explicitly stated that the demand for ecosystem services was assessed and spatially mapped. In this way, it was possible to examine articles that might describe spatial relationships and patterns between SPA and SDA.

Table 3.

Examined keyword combination. The highlighted keywords were used for further analysis as they address the mapping of ES.

\begin{tabular}{|l|l|l|}
\hline Keywords & \multicolumn{2}{l|}{ Occurrence } \\
\cline { 2 - 3 } & Scopus & ISI Web of Knowledge \\
\hline Ecosystem Service + Demand & 402 & 716 \\
\hline Ecosystem Service + Demand + Supply & 145 & 218 \\
\hline Ecosystem Service + Demand + Mapping & $\mathbf{4 4}$ & $\mathbf{9 7}$ \\
\hline
\end{tabular}

As Wolff et al. (2015) published a comprehensive review on mapping ES demand and was especially considered in this article, the search was limited to articles from 2015 to 2020. From this search, the relevant literature was selected by reading abstracts and examining the texts. A record was made of which definition of demand was used, who demands ES, whether mismatches were considered, which ES were investigated, which spatial representation of the demand for ES was chosen and which methods were used. 


\subsection{Development and structure of the adapted spatial-structural approach}

The illustrations and descriptions of the adapted spatial-structural approach were compiled, based on already-existing graphical representations, terms and explanations. These have been redesigned and reformulated to include the SDA. An overview of the central components is shown in Fig. 1. The components can be explained as follows:

\begin{tabular}{|c|c|c|c|}
\hline Symbol & Name & Description & Examples \\
\hline & $\begin{array}{l}\text { Service Providing } \\
\text { Area }\end{array}$ & $\begin{array}{l}\text { The area where the ES are } \\
\text { provided. }\end{array}$ & $\begin{array}{l}\text { Ecosystems, biotopes, } \\
\text { habitats, water bodies, } \\
\text { watersheds, land use types. }\end{array}$ \\
\hline & $\begin{array}{l}\text { Service Demanding } \\
\text { Area }\end{array}$ & $\begin{array}{l}\text { The area in which people's } \\
\text { needs or desires can be } \\
\text { located. }\end{array}$ & $\begin{array}{l}\text { Places where people live or } \\
\text { work (buildings, urban } \\
\text { areas); specific land use } \\
\text { types where ES are needed } \\
\text { (e. g. erosion control on } \\
\text { agricultural land). }\end{array}$ \\
\hline & $\begin{array}{l}\text { Service Benefitting } \\
\text { Area }\end{array}$ & $\begin{array}{l}\text { The area where people } \\
\text { knowingly or unknowingly } \\
\text { benefit from the ES of } \\
\text { interest. }\end{array}$ & $\begin{array}{l}\text { The area on agricultural land } \\
\text { that benefits from } \\
\text { pollination by wild bees } \\
\text { depends on the nesting sites } \\
\text { and flight range of wild bees. }\end{array}$ \\
\hline & $\begin{array}{l}\text { Service Connecting } \\
\text { Area }\end{array}$ & $\begin{array}{l}\text { The area where ES are } \\
\text { transported or 'flow' from } \\
\text { the Service Providing Area } \\
\text { to the Service Demanding } \\
\text { Area. } \\
\text { The area where people } \\
\text { actively access areas to } \\
\text { benefit from ES. }\end{array}$ & $\begin{array}{l}\text { The area between } \\
\text { agricultural land on which } \\
\text { crops grow and villages or } \\
\text { cities where food is } \\
\text { consumed. } \\
\text { The possible distance at } \\
\text { which fresh and cold air } \\
\text { provided in parks mixes with } \\
\text { the warmer air in built-up } \\
\text { areas. } \\
\text { The area between } \\
\text { residential areas and parks, } \\
\text { lakes, forests etc. }\end{array}$ \\
\hline
\end{tabular}

Figure 1.

Overview and explanations of the central components.

Service Providing Areas (SPA) locate areas where ES supply/potential emerge. These areas contain natural elements and may include parts or even whole ecosystems that represent complex, functional units of plant, animal and microorganism communities and their non-living environment (Potschin-Young et al. 2018). The most appropriate spatial units are those that are closely related to the ES concerned. These can be, for instance, biotopes, habitats, water bodies, watersheds, land-use types or the areas of impact of related ecosystem functions or processes (such as floodplains). As ecosystem condition, conservation, as well as land management measures are important factors influencing ES supply, these areas can consist of natural and anthropogenic elements and characteristics 
(Syrbe and Walz 2012, van Oudenhoven et al. 2012, Walz et al. 2017). La Notte et al. (2019) described how ecosystems (or, in this case, the SPAs) can play different roles in providing ES potential. They can: 1) increase the productivity of an ES (e.g. food production or raw materials); 2) influence the suitability of ecosystems for providing, for example, pollination services or suitable habitats; 3 ) act as a sink (when ES absorb matter or energy, such as in air filtration); 4) buffer matter or energy which flows through the SPA (e.g. flood regulation); or 5) form the area where intangibles, such as information or cultural identities, are generated (La Notte et al. 2019).

We propose that people's needs or desires can be spatially located and are an indication of Service Demanding Areas (SDA). When characterising the SDA, it should be kept in mind that the spatial location can vary with the selected ES demand type as well as with the group of people from whose perspective the expressed demand is to be presented. SDA often correspond to the usual location of people (urban areas, buildings), but can also be located with the help of closely related land-use types, on which the benefits of ES are intended to be received.

Service Connecting Areas (SCA) visualise the different forms of ES flows and transport mechanisms. As already mentioned above, the representation of the SCA is strongly scaledependent. Depending on the ES considered, the SCA can be represented by natural or anthropogenic elements (such as streams, rivers or human-made infrastructures). The spatial distance of impact and possible access restrictions or barriers should be taken into account in the presentation of the SCA as these are crucial in determining whether people can reach or benefit from ES. Often SCA can only be detected by conducting specific analyses, as is particularly the case with inter-regional ES flows (Schröter et al. 2018, Kleemann et al. 2020).

Service Benefitting Areas (SBA) represent the areas where people knowingly or unknowingly benefit from the ES of interest.

The various spatial relationships that can occur were ordered into three main categories:

1) In-situ: ES are provided and demanded in the same area (in situ). Since the ES do not have to "flow" or be transported, the benefits of these ES can also be located in the same area.

2) Directional connections: ES are not provided and demanded in the same area, but these areas are near each other, directional connections exist. The provided ES can "flow" through natural processes or people who demand these ES, actively access the SPA in order to benefit from provided ES.

3) Non-directional connections: ES are provided and demanded in areas with nondirectional connections. The provided ES "flow" through natural processes over long distances, ES products and goods (wood, food etc.) are transported to people who demand these things or people who demand these ES actively access the SPA to benefit from provided ES. 


\section{Results}

In the following sections, we will present the outcomes of the literature review and present the newly-introduced component of service demanding areas in the adapted spatialstructural approach in more detail and with examples.

\subsection{Literature review}

Altogether 33 articles were identified which addressed demand for ES. A detailed overview of the articles analysed and the definitions, ES, methods and scale of analysis used can be found in Suppl. materials 1, 2.

The articles looked at different ES at a varying level of detail (see Suppl. material 2). Nine articles focused only on one ES, 24 articles considered two or more ES. The demand for regulating ES was considered most frequently, with a popular focus on specific ES, such as global or local climate regulation, water flow regulation, air quality regulation and pollination. Amongst the cultural ES, the demand for nature-based recreation was most frequently assessed, followed by the demand for intangible services, such as natural heritage and intrinsic values of biodiversity. The demand for provisioning services received the least attention. Here, the demands for food, (drinking) water and raw materials were most often analysed.

The spatial scales of the case study areas varied from local to international, with regional studies being most predominant (21). Fifteen articles did not describe from which perspective ES demand had been assessed. In the remaining articles, it can be deduced which perspective was presented. In Quintas-Soriano et al. (2019), the demand for ES was assessed by randomly selected persons. In some papers, key or local stakeholders and/or experts assessed or estimated the demand for ES (Beichler 2015, Palacios-Agundez et al. 2015, Li et al. 2016, Palomo-Campesino et al. 2018, Kokkoris et al. 2019). Others assessed the demand of particular interest groups like vulnerable people (Cortinovis and Geneletti 2018), farmers (Chen et al. 2018), visitors/tourists (Schirpke et al. 2018, Zhao et al. 2019), people dependent on wild medicinal plants or certain consumers groups (Wolff et al. 2017). The demand of different population groups was also examined, identifying them as residents (Schirpke et al. 2018), rural population (Chen et al. 2018) or households (Sahle et al. 2018b, Yuan et al. 2019). Three articles used environmental quality standards (Baró et al. 2015, Baró et al. 2016, Chen et al. 2019), which are set by institutions to assess discrepancies as a proxy threshold to determine expected or required ecosystem conditions from a societal perspective demand.

Statistical/literature data was most commonly used for simple assessments and mapping of ES demand (18) (e.g. Baró et al. 2016). In contrast, only six articles used comprehensive models to calculate the demand for a few selected ES: recreation, pollination, flood regulation and wild medicinal plants (e.g. Wolff et al. 2017). Participatory methods were used in eight articles, including participatory mapping, qualitative participatory scenarios, preference assessments and various types of surveys (e.g. Beichler 2015, Palacios-Agundez et al. 2015, Quintas-Soriano et al. 2019). For example, 
interviewees expressed their estimation of the extent of a region's ES demand using the ES matrix look-up table method ( $\mathrm{Li}$ et al. 2016, Chen et al. 2018). Furthermore, results were analysed with different statistical and spatial analysis methods, such as principal component analysis, cluster analysis, multi-criteria analysis or spatial prioritisation (e.g. Verhagen et al. 2017, Schirpke et al. 2019a, Schirpke et al. 2019b). Some articles combined scenario-based analyses with trade-off analyses to consider and determine the effects of, for example, changes in land cover and land-use, land use management or policy and/or climate change (Goldenberg et al. 2017, Cimon-Morin and Poulin 2018, Cortinovis and Geneletti 2018, Sauter et al. 2019, Yuan et al. 2019). In 30 articles, a combination of methods was found. Most articles (29) analysed ES mismatches and tradeoffs, by comparing results from ES supply/potential with ES demand assessments.

\subsection{Demand for ecosystem services in a spatial-structural approach}

Fig. 2 illustrates possible types of spatial relations in the adapted ES spatial-structural approach in a generalised and simplified way.

Based on the spatial relationships presented above (Chapter 2.2), a distinction can be made between the following types of relationships between the SPA and SDA:

1) in situ: ES can be provided and demanded in the same area (in situ). The benefit of this ES can be found in the same area, as it does not require the ES to "flow" or be transported. There may still be areas where the ES is demanded, but not provided at this location. This can lead to an unmet demand. It is also possible that there are areas that provide the ES, but these ES are not used by people and, therefore, are not classified as SBA.

Example: Crop yield is influenced by ES which regulate and maintain soil quality. These ES can, however, only provide benefits in their immediate location. The benefits of these ES can be seen directly where soils with good natural soil quality are used, i.e. in the SDA. These ES can also be provided in areas like urban parks, but the benefits seen in urban parks are not related to food production. Gardens or agricultural land where these ES are not provided would display unmet demand.

2) There are several ways in which directional connections can occur between SPA and SDA:

2a) Central directional: ES are provided in an area surrounding the SDA. The ES provided "flow" through natural processes into the SDA, where the benefits can be used. However, the flow distance of the respective ES can be limited. Outside this range, there would remain unmet ES demand.

Example: City residents can benefit from the supply of fresh and cold air produced in the open spaces in the surrounding area that mixes with the warmer air in the built-up areas. As this distance is limited, people living in centrally located built-up areas may still need local climate regulation. 


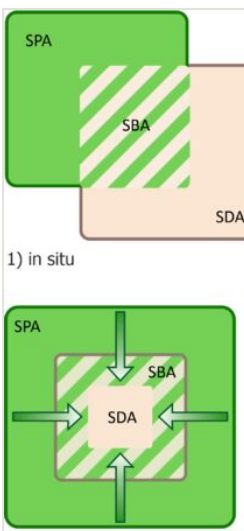

2a) Central directional

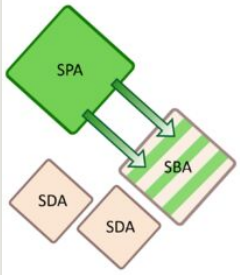

3a) Transport of commodities

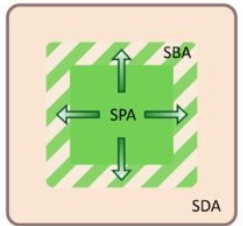

2b) Omnidirectional

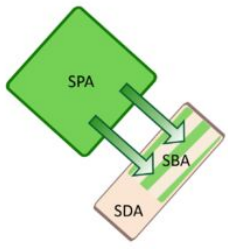

3b) Spatially separated, SCA determined by ecosystem functions

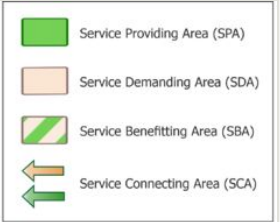

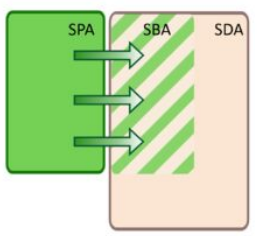

2c) Directional with predominant impact

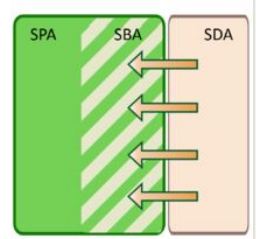

2d) Directional with predominant use direction

Figure 2.

Spatial-structural approach including Service Demanding Areas (SDA). Types of spatial relations of Service Providing Areas (SPA), Service Benefitting Areas (SBA) and Service Connecting Areas (SCA) (adapted and extended from Fisher et al. (2009), Syrbe and Walz (2012), Syrbe and Grunewald (2017), Walz et al. (2017) and with consideration of the work from Schröter et al. (2018), La Notte et al. (2019)).

2b) Omnidirectional: This case is similar to 2a), except that a central SPA provides benefits to a surrounding SDA.

Example: A park within a city provides fresh and cool air that mixes with the warmer air in the built-up areas. As this provision distance is limited, residents in more built-up areas cannot benefit from this ES type.

2c) Directional with a predominant impact direction: ES are provided in an area that is close to the SDA. The SCA is determined by ecological functions and processes, with a predominant direction of impact. If the SCA is missing, the SDA behind it cannot benefit from the respective ES.

Example: The residents of a built-up area are protected from storm surges by natural coastal protection through, for instance, dunes, coastal wetlands or seagrass. As not all coastal areas provide this ES type, there may be built-up areas not protected by natural coastal defences. These residents live in areas that are at higher risk of flooding. 
2d) Directional with a predominant use direction: This case is similar to $2 b$ ), except that there is a movement from the SDA to the SPA.

City residents can actively walk to urban parks for sport and recreational reasons. Using the natural environment helps the residents to stay fit. SCA can be used to display the distances that residents travel from their homes. However, some of the suitable urban green spaces may be too far and are, therefore, not used. There may also be urban settlements where the distance to any park or green area is too far. The demand of these people for the ES remains unfulfilled.

3) The SPA and SDA can be spatially separated from each other at greater distances, where non-directional connections exist. There are several circumstances:

3a) The areas where ES are provided and demanded are spatially separated. However, there is an SCA, determined by ecological functions and processes, which ensures that the benefits of these ES take place where they are in demand. Nevertheless, there may still be areas that do not benefit from the ES, for example, due to barriers influencing the SCA.

Example: A floodplain upstream protects residents in a built-up area against river flood events. As there may also be urban areas that cannot benefit from the ES due to, for instance, geographical reasons, an unmet demand may exist.

3b) Movement: This case is similar to $2 \mathrm{~d}$, except that people actively access areas at greater distances in order to benefit from the ES provided there.

Example: People can travel around the world to enjoy and benefit from ES provided by aesthetic landscapes. As some places are too far away or inaccessible due to restrictions, these areas do not represent SBA. Similarly, there may be people who cannot travel or for whom the places are too far away, which may result in an unmet demand.

3c) Transport of commodities: SDA and SPA are spatially separated; thus, the connection area is determined by the transport of goods and materials or information. Areas, where these things are transported, can benefit from the ES. However, it may also be that these things are not transported into certain areas, which means that the demand is still unsatisfied.

Example: Agricultural land provides crops, fruits and vegetables that can be transported to urban areas worldwide where people live and need food. However, there may be (for various reasons) no food transport to certain urban areas, so residents cannot benefit from this food supply, which, in the worst case, can lead to hunger.

\section{Discussion}

This article contributes to the conceptual understanding about ES demand and aims to illustrate that not only the areas where the benefits of ES arise and can be used by people should be considered, but also that it is essential to look at the areas where the demand for 
these ES arise in the first place. By taking this aspect into account, interventions can be explored that could strengthen the role of healthy ecosystems - especially where people are particularly dependent on nature - and where solutions should focus on reducing ES demand to protect the ecosystem (Chaplin-Kramer et al. 2019, Chen et al. 2019).

We hope that with the addition of SDA to existing spatial concepts, the difference between ES demand and benefits can be highlighted. In addition, the schematic illustrations and examples show that similar spatial connections exist that significantly influence the fulfilment of ES demand.

\subsection{Ecosystem service demand is multifaceted}

Spatially-explicit mapping of ES demand is challenging given that demand is multifaceted and can change over time.

ES are not delivered to society as a single group of beneficiaries; the groups differ in their cultural and demographic characteristics (such as age, gender and ethnicity), have different levels of education, interests, motivations, financial resources or consumption patterns (Pascual et al. 2014, Pascual et al. 2017, Hegetschweiler et al. 2017). Therefore, people demand ES in very different and often contradictory ways, leading to trade-offs between the interests of different stakeholders (Cavender-Bares et al. 2015).

Often, only a few actors (such as farmers, landowners, business enterprises or institutions) have an impact on land-use change and the ES flow mechanism and, thus, play a crucial role in creating, distributing and meeting ES demand (La Notte et al. 2019, Watson et al. 2019). In particular, institutions can strongly influence the demand for specific ES through land-use decisions, guidelines, environmental quality standards or policy objectives (Geijzendorffer and Roche 2014, Baró et al. 2015, Baró et al. 2016, Chen et al. 2019). For example, Schulp et al. (2014) have shown how demand for pollination increased after the European Commission started to promote and subsidise pollinator-dependent crops (oilseed rape, sunflower and other oil crops) with the EU Biofuels Directive (European Commission 2009). Due to the increasingly negative impact of agricultural intensification on ES potential, the authors call for further ecosystem protection at the EU level to help meet demand for pollination. Identifying these 'enabling actors' (La Notte and Dalmazzone 2018) and the geographic and policy scale from which they influence land use helps to better understand who is responsible for land-use change and what policy or management interventions are needed to enhance or maintain ES successfully (Darvill and Lindo 2015, Geijzendorffer et al. 2015).

In general, as with all ES assessments, the spatial scale also plays an essential role in ES demand (Geijzendorffer and Roche 2014). The illustrations and examples of the spatial concept presented here show that the spatial distribution and connection of the SPA and SDA can vary greatly depending on the ES. Therefore, it is advisable to examine possible SPA and SDA for each ES and determine whether specific patterns can be identified in different human-environment systems. 
As demand varies from ES to ES, it can also be met in diverse ways. In many cases, ES supply is actively co-produced and increased through human activities and interventions (Bennett et al. 2015, Fischer and Eastwood 2016) or the benefits are imported in the form of products and goods from other regions. For example, food production on agricultural land is enhanced through various agricultural interventions (Wiggering et al. 2016, Bethwell et al. 2021) and the harvest is subsequently transported to beneficiaries (Ala-Hulkko et al. 2019). Strategically planned networks, such as green infrastructure, safeguard or enhance recreational opportunities (Hegetschweiler et al. 2017), multiple ES and support biodiversity (Chen et al. 2019, European Commission 2019, Hersperger et al. 2020).

The high demand for ES and trade-offs between ES can also be reduced without increasing ES supply through intelligent policy-making, for example, by increasing prices, fees or taxes on certain products (Fisher et al. 2009), by restricting access to fragile ecosystems (Schägner et al. 2016), through planning laws that aim, for instance, at social and environmental justice (Jacobs et al. 2016, Cortinovis and Geneletti 2018) or through agreements on climate, ecosystem and biodiversity. This option is often a solution for regulating $E S$, as the underlying ecosystem processes and functions often take place over longer distances and the benefits cannot be used or consumed directly (Sauter et al. 2019). The demand for global climate regulation, for example, can be expressed as a demand for a global ecosystem state in which $\mathrm{CO}_{2}$ and other GHG emissions, as major contributors to global climate change, are adequately sequestered and stored at a global scale (Burkhard et al. 2012, Baró et al. 2015, Sahle et al. 2018a, Cimon-Morin and Poulin 2018). However, alternative scales, data and indicators can also indicate ES demand mismatches for these ES (Rioux et al. 2019). For example, it can be shown at the local level whether anthropogenic emissions exceed local $\mathrm{CO}_{2}$ sequestration and storage capacity (Zhao and Sander 2015, Sahle et al. 2018a, González-García et al. 2020). Such a study is politically relevant as it can show where and why $\mathrm{CO}_{2}$ emission levels exceed legally binding $\mathrm{CO}_{2}$ emission targets (Baró et al. 2015, Chen et al. 2019, Sauter et al. 2019).

\subsection{Mapping ecosystem service demand}

As with all mapping assessments, data availability is a crucial factor for spatial mapping of ES demand. It is noticeable that, in the studied articles, demand for ES mainly was assessed and analysed, based on simple statistical and/or literature data (see Suppl. material 1). The use of statistical and/or literature data, look-up tables or the ES matrix method is well-suited for comparatively quick and large-scale analyses, especially when implementing comprehensive process-based ES models would be too resource-intensive (Sauter et al. 2019, Campagne et al. 2020). In this way, relatively simple, yet realistic, estimates can be generated that show spatial distribution patterns (Goldenberg et al. 2017). However, it should be kept in mind that the complexity of ES demand is then represented in a simplified way, which may have consequences in identifying or not identifying ES mismatches and trade-offs (Li et al. 2016). 
Furthermore, ES demand is often derived from a land-use/land-cover perspective. This approach assumes that certain land-use types have a higher demand for the benefits of the corresponding ES. For example, studies have determined the demand for pollination by the size of vegetable gardens in residential or agricultural areas (Schulp et al. 2014, Rioux et al. 2019, Zhao et al. 2019). A higher demand for ES is often attributed to particularly vulnerable land-use types at higher risk during extreme events. For example, high demand for ES for flood regulation has been attributed to those land-use types that are most likely to experience negative impacts for people during flood events (Nedkov and Burkhard 2012). A similar attribution can also be observed in assessing and managing flood risk in the EU (Directive 2007/60/EC). However, further aspects of demand are also considered, namely the potentially negative impacts of floods on human health, infrastructure, nature conservation areas and cultural heritage (European Union 2007).

The frequent use of proxy indicators (e.g. population numbers or building density, air quality and proximity to green spaces) (Baró et al. 2015) only provides information on the potential use of ES and does not take into account the diverse demands of stakeholders. So far, only a few authors have taken up the challenge of considering the demands of different user groups (e.g. residents, farmers and tourists) to represent different interests or concerns (Chen et al. 2018, Schirpke et al. 2018, Chen et al. 2019). However, such an investigation requires a comprehensive data basis and requires a higher methodological effort.

Various participatory methods are available to indicate the ES demand of different stakeholder groups (see, for example, Cavender-Bares et al. 2015, Palacios-Agundez et al. 2015, La Rosa et al. 2016, Harrison et al. 2018, Quintas-Soriano et al. 2019). Although these methods may not provide accurate geographical data, they provide valuable ES information that is otherwise difficult to assess, such as cultural ES (Beichler 2015, Palomo-Campesino et al. 2018). However, additional methods should be included for ES that are rarely known or often hardly perceived as relevant by stakeholders (Kaye-Zwiebel and King 2014, Quintas-Soriano et al. 2019). Since ES demand is multifaceted, using multiple methods and data types from different disciplines can significantly increase the knowledge and applicability of the results (Milcu et al. 2013, Flood et al. 2021).

In the reviewed articles, ES mismatch analyses were mostly conducted through comparatively simple supply-demand comparisons that express the degree of (im)balance between the ES supply and demand (e.g. Li et al. 2016, González-García et al. 2020). The relationship between ES supply and demand can be strongly influenced by site-specific and short-term aspects, such as weather conditions, land-use/land-cover changes and landscape features, which can be included in the analysis and reveal further underlying correlations (Hegetschweiler et al. 2017). Such comprehensive studies have been conducted, for example, by Schirpke et al. (2018) and Schirpke et al. (2019a), where the use of landscape, temporal and socio-ecological variables was able to identify and explain the heterogeneous distribution of ES bundles in the European Alps.

Interestingly, significant differences in the quality of ES supply and demand assessments can be observed in some articles. The difference in quality is also acknowledged as a 
limitation by the authors themselves and has also been criticised in other studies (e.g. Czúcz et al. 2020, González-García et al. 2020). Comprehensive modelling of ES demand has only been carried out in comparatively few studies (e.g. Wolff et al. 2017). The reasons for this could be that, so far, suitable demand indicators have only been integrated into ready-to-use models for a few ES (see, for example, InVEST (The Natural Capital Project (NatCap) 2021), ESTIMAP (Zulian 2016) or ARIES (Villa et al. 2014)).

\subsection{Limitations}

This study complements previous spatial structural approaches with SDA, but also has some methodological limitations. First, we are aware that ES research is a very dynamic field and that there may now be other relevant sources that consider and map ES demand. Second, the selection of our keywords had a major impact on identifying relevant articles and narrowing down the results. This problem has been highlighted in other review articles (e.g. La Rosa et al. 2016).

In the process of editing this article, it became more and more apparent that; a) there continues to be a heterogeneous understanding of key terms and b) that, accordingly, specific key terms are also used differently in ES assessment, mapping or accounting literature. In the official reports of the accounting community, "ES demand" is not used as an independent term (see also Table 1 in the Introduction) - instead, the focus here is on "use of ES" or "actual flow" of services. Expanding the keywords in the literature search with, for example, these terms could have identified more sources.

Given the diversity of ES and the different influencing factors that affect and respond to changes in ES demand, a narrow definition is often avoided to reflect this diversity (Wolff et al. 2015). This flexibility is often even desired in the holistic ES approach to facilitate discussions between disciplines (Czúcz et al. 2020, Grunewald et al. 2021). However, in many of the articles reviewed, the demand for ES was not sufficiently described, leading to further confusion. Overall, the different understandings pose a challenge for the transferability and comparability of the methodological approaches and the ability to communicate and apply the results in policy, land-use management or spatial planning. Understanding the diversely interpreted ES terms is particularly challenging for non-native speakers, especially when English terms themselves contain subtle nuances of meaning and there are no direct translations into their native language (Dłużewska 2016). Therefore, it should be communicated how the ES concept terms are understood and what indicators have been used to represent them.

We would like to emphasise that this paper only intends to provide an initial overview of the spatial relationships between the different components of the ES concept and to make a valuable contribution to future considerations in this field. This being the case, various aspects (e.g. temporal changes) that influence the distribution of the ES are not yet included in the figures or examples used in this paper. 


\section{Conclusions}

Healthy ecosystems play a key role in meeting ES demand by providing, for example, food, clean drinking water, security and protection against natural hazards and a wide range of recreational opportunities. The ES approach provides a holistic framework to examine how nature can sustainably fulfil ES demand.

Matching ES supply and demand, based on conservation and sustainable use of ecosystems and their services, can help safeguard human well-being by avoiding unmet demands. Information and data from respective ES assessments (including the comprehensive and robust data provided by ecosystem and natural capital accounting following SEEA) that integrate ecological, social-cultural and economic value domains, provide the evidence base for appropriate public and private decision-making on relevant spatial and temporal scales - from local to global and from short- to long-term (Goldenberg et al. 2017, Ala-Hulkko et al. 2019, González-García et al. 2020, Vysna et al. 2021).

Having analysed the selected scientific articles, three issues have emerged that can be addressed to strengthen the assessment of ES demand and, thus, ES mismatch analyses. Firstly, different studies perceive ES demand differently and it is important to clarify what is meant by ES demand. Overall, a clear distinction between ES supply, potential, flow and demand is mandatory to consider the different components of complex ES delivery from nature to society. ES research requires both a common internal lexicon and the flexibility to adapt the terminology used in external publications/communications regarding the desired field of application in science, policy, business and society. This would help to increase the mutual understanding within the ES concept and improve the chances of its implementation in related fields of applications, such as, for example, urban and regional planning (Scott et al. 2018).

Secondly, it must be kept in mind that there are different ways to express human needs and desires and that demand is thus multifaceted. Including the full range of stakeholders' perceptions, needs and desires broaden the picture of societal demand for ES (Bennett et al. 2015). It is often the case that multiple stakeholders must be brought on board to elaborate on important land-use decisions. Thus, it is crucial to look at these actors and the spatial and temporal dimensions of the mutual inter-relationships between ES supply and demand in order to identify the most effective approaches for achieving ES sustainability (Villamagna et al. 2013, Geijzendorffer et al. 2015).

Thirdly, to inform decision-makers about reducing ES trade-offs and mismatches, meaningful interpretations between ES supply and demand must be available. The adapted spatial-structural approach is a helpful (visual) support for understanding the ES concept's spatial components for identifying areas of interest. Studies vary widely in terms of ES demand indicators, data and evaluation methods used. This highlights the lack of a systematic methodological framework or the policy triage system to guide ES research, which comprehensively measures comparable units and can link existing information on ES supply, demand and benefits (Honey-Rosés and Pendleton 2013). Existing 
frameworks, such as the MAES framework, provide a valuable basis, but need to address the ES demand side strongly (Burkhard and Maes 2017, Heckwolf et al. 2020).

Understandably, a precise assessment of the demand for ES is challenging, as both environmental and socio-economic systems are highly complex as well as spatially and temporally variable. Uncertainties about the interaction of ES supply and demand can, for instance, arise from feedback loops (Stosch et al. 2017). For example, significant socioeconomic and cultural changes have occurred due to the current COVID-19 pandemic and are changing the perception and use of the ES provided (Rousseau and Deschacht 2020). The current negative developments related to the pandemic, such as travel restrictions, increase the importance, but also the use of nature-based recreational activities in the immediate vicinity (Kleinschroth and Kowarik 2020, Venter et al. 2020). With the integration of the SDA, we hope that the spatial connections of the complex ES delivery will be more strongly emphasised.

\section{Acknowledgements}

The authors would like to thank the editor and the reviewers for their useful comments and literature recommendations. Their valuable suggestions helped us to improve the manuscript significantly. Many thanks to Henning Schumacher for his contributions to the literature review and Angie Faust and Matthew Cruickshank for their valuable feedback and English proofreading.

\section{Funding program}

This study was part of the research project ÖSKKIP (Ecosystem Services of Urban Regions - Mapping, Communicating and Integrating into Planning to conserve biodiversity during a changing climate) funded by the German Ministry of Education and Research (BMBF) under the funding code FKZ 16LC1604B. The publication of this article was funded by the Open Access Fund of the Leibniz Universität Hannover.

\section{Author contributions}

Literature review/data collection: Claudia Dworczyk

Concept development: Claudia Dworczyk and Benjamin Burkhard

Article writing: Claudia Dworczyk and Benjamin Burkhard

\section{Conflicts of interest}

None. 


\section{References}

- $\quad$ Ala-Hulkko T, Kotavaara O, Alahuhta J, Hjort J (2019) Mapping supply and demand of a provisioning ecosystem service across Europe. Ecological Indicators 103: 520-529. https://doi.org/10.1016/i.ecolind.2019.04.049

- $\quad$ Bagstad K, Johnson G, Voigt B, Villa F (2013) Spatial dynamics of ecosystem service flows: A comprehensive approach to quantifying actual services. Ecosystem Services 4: 117-125. https://doi.org/10.1016/j.ecoser.2012.07.012

- $\quad$ Baró F, Haase D, Gómez-Baggethun E, Frantzeskaki N (2015) Mismatches between ecosystem services supply and demand in urban areas: A quantitative assessment in five European cities. Ecological Indicators 55: 146-158. https://doi.org/10.1016/j.ecolind. 2015.03.013

- $\quad$ Baró F, Palomo I, Zulian G, Vizcaino P, Haase D, Gómez-Baggethun E (2016) Mapping ecosystem service capacity, flow and demand for landscape and urban planning: A case study in the Barcelona metropolitan region. Land Use Policy 57: 405-417.

https://doi.org/10.1016/j.landusepol.2016.06.006

- $\quad$ Bastian O, Haase D, Grunewald K (2012) Ecosystem properties, potentials and services - The EPPS conceptual framework and an urban application example. Ecological Indicators 21: 7-16. https://doi.org/10.1016/j.ecolind.2011.03.014

- Beichler SA (2015) Exploring the link between supply and demand of cultural ecosystem services - towards an integrated vulnerability assessment. International Journal of Biodiversity Science, Ecosystem Services \& Management 11 (3): 250-263. https://doi.org/10.1080/21513732.2015.1059891

- Bennett E, Cramer W, Begossi A, Cundill G, Díaz S, Egoh B, Geijzendorffer I, Krug C, Lavorel S, Lazos E, Lebel L, Martín-López B, Meyfroidt P, Mooney H, Nel J, Pascual U, Payet K, Harguindeguy NP, Peterson G, Prieur-Richard A, Reyers B, Roebeling P, Seppelt R, Solan M, Tschakert P, Tscharntke T, Turner BL, Verburg P, Viglizzo E, White PL, Woodward G (2015) Linking biodiversity, ecosystem services, and human wellbeing: three challenges for designing research for sustainability. Current Opinion in Environmental Sustainability 14: 76-85. https://doi.org/10.1016/j.cosust.2015.03.007

- $\quad$ Bethwell C, Burkhard B, Daedlow K, Sattler C, Reckling M, Zander P (2021) Towards an enhanced indication of provisioning ecosystem services in agro-ecosystems. Environmental Monitoring and Assessment 193 https://doi.org/10.1007/s10661020-08816-y

- $\quad$ Bryan B, Ye Y, Zhang J, Connor J (2018) Land-use change impacts on ecosystem services value: Incorporating the scarcity effects of supply and demand dynamics. Ecosystem Services 32: 144-157. https://doi.org/10.1016/j.ecoser.2018.07.002

- $\quad$ Burkhard B, Kroll F, Müller F, Windhorst W (2009) Landscapes' capacities to provide ecosystem services - A concept for land-cover based assessments. Landscape Online 15: 1-22. https://doi.org/10.3097/LO.200915

- Burkhard B, Kroll F, Nedkov S, Müller F (2012) Mapping ecosystem service supply, demand and budgets. Ecological Indicators 21: 17-29. https://doi.org/10.1016/j.ecolind. 2011.06.019

- $\quad$ Burkhard B, Kandziora M, Hou Y, Müller F (2014) Ecosystem service potentials, flows and demands-concepts for spatial localisation, indication and quantification. Landscape Online 34: 1-32. https://doi.org/10.3097/LO.201434 
- $\quad$ Burkhard B, Maes J (Eds) (2017) Mapping Ecosystem Services. Pensoft Publishers, Sofia, Bulgaria, 378 pp. [ISBN 978-954-642-830-1] https://doi.org/10.3897/ab.e12837

- $\quad$ Campagne CS, Roche P, Müller F, Burkhard B (2020) Ten years of ecosystem services matrix: Review of a (r)evolution. One Ecosystem 5 https://doi.org/10.3897/oneeco. $\underline{5 . e 51103}$

- $\quad$ Cavender-Bares J, Polasky S, King E, Balvanera P (2015) A sustainability framework for assessing trade-offs in ecosystem services. Ecology and Society 20 (1).

https://doi.org/10.5751/ES-06917-200117

- $\quad$ Chaplin-Kramer R, Sharp RP, Weil C, Bennett EM, Pascual U, Arkema KK, Brauman KA, Bryant BP, Guerry AD, Haddad NM, Hamann M, Hamel P, Johnson JA, Mandle L, Pereira HM, Polasky S, Ruckelshaus M, Shaw MR, Silver JM, Vogl AL, Daily GC (2019) Global modeling of nature's contributions to people. Science (New York, N.Y.) 366 (6462): 255-258. https://doi.org/10.1126/science.aaw3372

- Chen J, Jiang B, Bai Y, Xu X, Alatalo J (2019) Quantifying ecosystem services supply and demand shortfalls and mismatches for management optimisation. The Science of the Total Environment 650: 1426-1439. https://doi.org/10.1016/j.scitotenv.2018.09.126

- $\quad$ Chen Y, Yu Z, Li X, Li P (2018) How agricultural multiple ecosystem services respond to socioeconomic factors in Mengyin County, China. The Science of the Total Environment 630: 1003-1015. https://doi.org/10.1016/i.scitotenv.2018.02.187

- Cimon-Morin J, Poulin M (2018) Setting conservation priorities in cities: approaches, targets and planning units adapted to wetland biodiversity and ecosystem services. Landscape Ecology 33 (11): 1975-1995. https://doi.org/10.1007/s10980-018-0707-z

- Cortinovis C, Geneletti D (2018) Mapping and assessing ecosystem services to support urban planning: A case study on brownfield regeneration in Trento, Italy. One Ecosystem 3 https://doi.org/10.3897/oneeco.3.e25477

- Czúcz B, Haines-Young R, Kiss M, Bereczki K, Kertész M, Vári Á, Potschin-Young M, Arany I (2020) Ecosystem service indicators along the cascade: How do assessment and mapping studies position their indicators? Ecological Indicators 118 https://doi.org/ 10.1016/j.ecolind.2020.106729

- $\quad$ Darvill R, Lindo Z (2015) The inclusion of stakeholders and cultural ecosystem services in land management trade-off decisions using an ecosystem services approach. Landscape Ecology 31 (3): 533-545. https://doi.org/10.1007/s10980-015-0260-y

- Dłużewska A (2016) Cultural Ecosystem Services - Framework, Theories and Practices. PROBLEMY EKOROZWOJU - PROBLEMS OF SUSTAINABLE DEVELOPMENT 12 (1): 101-110.

- European Commission (2009) Directive 2009/28/EC of the European Parliament and of the Council of 23 April 2009 on the Promotion of the use of Energy from Renewable Sources and Amending and Subsequently Repealing Directives 2001/77/EC and 2003/30/EC.

- European Commission (2019) Review of progress on implementation of the EU green infrastructure strategy. $\operatorname{COM}(2019) 236$ final. Publications Office of the European Union, Luxembourg. https://doi.org/10.2779/41957

- European Union (2007) Directive 2007/60/EC of the European Parliament and of the Council of 23 October 2007 on the assessment and management of flood risks. Official Journal of the European Union 
- $\quad$ European Union (Ed.) (2011) The EU Biodiversity Strategy to 2020. Publications Office of the European Union, Luxembourg. [ISBN 978-92-79-20762-4] https://doi.org/ $\underline{10.2779 / 39229}$

- Fischer A, Eastwood A (2016) Coproduction of ecosystem services as human-nature interactions-An analytical framework. Land Use Policy 52: 41-50. https://doi.org/ 10.1016/j.landusepol.2015.12.004

- $\quad$ Fisher B, Turner RK, Morling P (2009) Defining and classifying ecosystem services for decision making. Ecological Economics 68 (3): 643-653. https://doi.org/10.1016/ j.ecolecon.2008.09.014

- $\quad$ Flood K, Mahon M, McDonagh J (2021) Assigning value to cultural ecosystem services: The significance of memory and imagination in the conservation of Irish peatlands. Ecosystem Services 50 https://doi.org/10.1016/j.ecoser.2021.101326

- Geijzendorffer I, Martín-López B, Roche P (2015) Improving the identification of mismatches in ecosystem services assessments. Ecological Indicators 52: 320-331. https://doi.org/10.1016/j.ecolind.2014.12.016

- $\quad$ Geijzendorffer IR, Roche PK (2014) The relevant scales of ecosystem services demand. Ecosystem Services 10: 49-51. https://doi.org/10.1016/j.ecoser.2014.09.002

- $\quad$ Goldenberg R, Kalantari Z, Cvetkovic V, Mörtberg U, Deal B, Destouni G (2017) Distinction, quantification and mapping of potential and realized supply-demand of flowdependent ecosystem services. The Science of the Total Environment 593-594:

599-609. https://doi.org/10.1016/j.scitotenv.2017.03.130

- González-García A, Palomo I, González J, López C, Montes C (2020) Quantifying spatial supply-demand mismatches in ecosystem services provides insights for landuse planning. Land Use Policy 94: 104493. https://doi.org/10.1016/j.landusepol. 2020.104493

- Grunewald K, Bastian O, Louda J, Arcidiacono A, Brzoska P, Bue M, Cetin NI, Dworczyk C, Dubova L, Fitch A, Jones L, La Rosa D, Mascarenhas A, Ronchi S, Schlaepfer MA, Sikorska D, Tezer A (2021) Lessons learned from implementing the ecosystem services concept in urban planning. Ecosystem Services 49 https://doi.org/ 10.1016/j.ecoser.2021.101273

- Harrison P, Dunford R, Barton D, Kelemen E, Martín-López B, Norton L, Termansen M, Saarikoski H, Hendriks K, Gómez-Baggethun E, Czúcz B, García-Llorente M, Howard D, Jacobs S, Karlsen M, Kopperoinen L, Madsen A, Rusch G, van Eupen M, Verweij P, Smith R, Tuomasjukka D, Zulian G (2018) Selecting methods for ecosystem service assessment: A decision tree approach. Ecosystem Services 29: 481-498. https://doi.org/ 10.1016/j.ecoser.2017.09.016

- Heckwolf M, Peterson A, Jänes H, Horne P, Künne J, Liversage K, Sajeva M, Reusch TH, Kotta J (2020) From ecosystems to socio-economic benefits: A systematic review of coastal ecosystem services in the Baltic Sea. The Science of the Total Environment 755: 142565. https://doi.org/10.1016/j.scitotenv.2020.142565

- Hegetschweiler KT, de Vries S, Arnberger A, Bell S, Brennan M, Siter N, Olafsson AS, Voigt A, Hunziker M (2017) Linking demand and supply factors in identifying cultural ecosystem services of urban green infrastructures: A review of European studies. Urban Forestry \& Urban Greening 21: 48-59. https://doi.org/10.1016/j.ufug.2016.11.002

- Hersperger A, Bürgi M, Wende W, Bacău S, Grădinaru S (2020) Does landscape play a role in strategic spatial planning of European urban regions? Landscape and Urban Planning 194: 103702. https://doi.org/10.1016/j.landurbplan.2019.103702 
- Honey-Rosés J, Pendleton L (2013) A demand driven research agenda for ecosystem services. Ecosystem Services 5: 160-162. https://doi.org/10.1016/j.ecoser.2013.04.007

- $\quad$ IPBES (2019) Summary for policymakers of the global assessment report on biodiversity and ecosystem services of the Intergovernmental Science-Policy Platform on Biodiversity and Ecosystem Services. S. Díaz, J. Settele, E. S. Brondízio E.S., H. T. Ngo, M. Guèze, J. Agard, A. Arneth, P. Balvanera, K. A. Brauman, S. H. M. Butchart, K. M. A. Chan, L. A. Garibaldi, K. Ichii, J. Liu, S. M. Subramanian, G. F. Midgley, P. Miloslavich, Z. Molnár, D. Obura, A. Pfaff, S. Polasky, A. Purvis, J. Razzaque, B. Reyers, R. Roy Chowdhury, Y. J. Shin, I. J. Visseren-Hamakers, K. J. Willis, and C. N. Zayas (eds.). IPBES secretariat, Bonn, Germany.

- Jacobs S, Dendoncker N, Martín-López B, Barton DN, Gomez-Baggethun E, Boeraeve F, McGrath F, Vierikko K, Geneletti D, Sevecke K, Pipart N, Primmer E, Mederly P, Schmidt S, Aragão A, Baral H, Bark R, Briceno T, Brogna D, Cabral P, de Vreese R, Liquete C, Mueller H, Peh K-, Phelan A, Rincón A, Rogers S, Turkelboom F, van Reeth W, van Zanten B, Wam HK, Washbourne C (2016) A new valuation school: Integrating diverse values of nature in resource and land use decisions. Ecosystem Services 22: 213-220. https://doi.org/10.1016/j.ecoser.2016.11.007

- Jax K, Barton D, Chan KA, de Groot R, Doyle U, Eser U, Görg C, Gómez-Baggethun E, Griewald $Y$, Haber W, Haines-Young R, Heink U, Jahn T, Joosten H, Kerschbaumer L, Korn H, Luck G, Matzdorf B, Muraca B, Neßhöver C, Norton B, Ott K, Potschin M, Rauschmayer F, von Haaren C, Wichmann S (2013) Ecosystem services and ethics. Ecological Economics 93: 260-268. https://doi.org/10.1016/j.ecolecon.2013.06.008

- Kaye-Zwiebel E, King E (2014) Kenyan pastoralist societies in transition: varying perceptions of the value of ecosystem services. Ecology and Society 19 (3).

https://doi.org/10.5751/ES-06753-190317

- Kleemann J, Schröter M, Bagstad K, Kuhlicke C, Kastner T, Fridman D, Schulp CE, Wolff S, Martínez-López J, Koellner T, Arnhold S, Martín-López B, Marques A, LopezHoffman L, Liu J, Kissinger M, Guerra CA, Bonn A (2020) Quantifying interregional flows of multiple ecosystem services - A case study for Germany. Global Environmental Change 61: 102051. https://doi.org/10.1016/j.gloenvcha.2020.102051

- Kleinschroth F, Kowarik I (2020) COVID-19 crisis demonstrates the urgent need for urban greenspaces. Frontiers in Ecology and the Environment 18 (6): 318-319. https://doi.org/10.1002/fee.2230

- Kokkoris I, Bekri E, Skuras D, Vlami V, Zogaris S, Maroulis G, Dimopoulos D, Dimopoulos $P$ (2019) Integrating MAES implementation into protected area management under climate change: A fine-scale application in Greece. The Science of the Total Environment 695: 133530. https://doi.org/10.1016/j.scitotenv.2019.07.336

- La Notte A, Dalmazzone S (2018) Sustainability assessment and causality nexus through ecosystem service accounting: The case of water purification in Europe. Journal of Environmental Management 223: 964-974. https://doi.org/10.1016/j.jenvman. 2018.06.072

- La Notte A, Marques A (2019) Adjusted macroeconomic indicators to account for ecosystem degradation: an illustrative example. Ecosystem Health and Sustainability 5 (1): 133-143. https://doi.org/10.1080/20964129.2019.1634979

- La Notte A, Vallecillo S, Marques A, Maes J (2019) Beyond the economic boundaries to account for ecosystem services. Ecosystem Services 35: 116-129. https://doi.org/ 10.1016/j.ecoser.2018.12.007 
- La Rosa D, Spyra M, Inostroza L (2016) Indicators of Cultural Ecosystem Services for urban planning: A review. Ecological Indicators 61: 74-89. https://doi.org/10.1016/ j.ecolind.2015.04.028

- $\quad$ Li J, Jiang H, Bai Y, Alatalo J, Li X, Jiang H, Liu G, Xu J (2016) Indicators for spatialtemporal comparisons of ecosystem service status between regions: A case study of the Taihu River Basin, China. Ecological Indicators 60: 1008-1016. https://doi.org/ 10.1016/j.ecolind.2015.09.002

- Maes J, Teller A, Erhard M, Grizzetti B, Barredo JI, Paracchini ML, Condé S, Somma F, Orgiazzi A, Jones A, Zulian A, Vallecilo S, Petersen JE, Marquardt D, Kovacevic V, Abdul Malak D, Marin Al, Czúcz B, Mauri A, Loffler P, Bastrup-Birk A, Biala K, Christiansen T, Werner B (2018) Mapping and Assessment of Ecosystems and their Services. An analytical framework for mapping and assessment of ecosystem condition in EU. Publications Office of the European Union, Luxembourg.

- Maes J, Teller A, Erhard M, Condé S, Vallecillo S, Barredo J, Paracchini ML, Abdul Malak D, Trombetti M, Vigiak O, Zulian G, Addamo A, Grizzetti B, Somma F, Hagyo A, Vogt P, Polce C, Jones A, Marin A, Ivits E, Mauri A, Rega C, Czúcz B, Ceccherini G, Pisoni E, Ceglar A, De Palma P, Cerrani I, Meroni M, Caudullo G, Lugato E, Vogt J, Spinoni J, Cammalleri C, Bastrup-Birk A, San Miguel J, San Román S, Kristensen P, Christiansen T, Zal N, de Roo A, Cardoso AC, Pistocchi A, Del Barrio Alvarellos I, Tsiamis K, Gervasini E, Deriu I, La Notte A, Abad Viñas R, Vizzarri M, Camia A, Robert N, Kakoulaki G, Bendito EG, Panagos P, Ballabio C, Scarpa S, Montanarella L, Orgiazzi A, Fernandez Ugalde O, Santos-Martín F (2020) Mapping and Assessment of Ecosystems and their Services: An EU ecosystem assessment. Publications Office of the European Union, Luxembourg.

- Maslow A (1954) Motivation und Personality. Harper \& Row, Publishers, Inc., New York. [ISBN 978-8131711491]

- Milcu Al, Hanspach J, Abson D, Fischer J (2013) Cultural Ecosystem Services: A Literature Review and Prospects for Future Research. Ecology and Society 18 (3). https://doi.org/10.5751/ES-05790-180344

- Millennium Ecosystem Assessment (2005) Ecosystems and Human Wellbeing: Current State and Trends. Island Press, Washington DC. [ISBN 1-55963-227-5]

- Nedkov S, Burkhard B (2012) Flood regulating ecosystem services-Mapping supply and demand, in the Etropole municipality, Bulgaria. Ecological Indicators 21: 67-79. https://doi.org/10.1016/j.ecolind.2011.06.022

- Oxford University Press (OUP) (2020) English dictionary [online]. Definition of capacity, demand, flow, potential, supply. https://www.lexico.com/. Accessed on: 2020-12-01.

- Palacios-Agundez I, Onaindia M, Potschin M, Tratalos J, Madariaga I, Haines-Young R (2015) Relevance for decision making of spatially explicit, participatory scenarios for ecosystem services in an area of a high current demand. Environmental Science \& Policy 54: 199-209. https://doi.org/10.1016/j.envsci.2015.07.002

- Palomo-Campesino S, Palomo I, Moreno J, González J (2018) Characterising the ruralurban gradient through the participatory mapping of ecosystem services: insights for landscape planning. One Ecosystem 3: e24487. https://doi.org/10.3897/oneeco. 3.e24487

- Pascual U, Phelps J, Garmendia E, Brown K, Corbera E, Martin A, Gomez-Baggethun E, Muradian R (2014) Social Equity Matters in Payments for Ecosystem Services. BioScience 64 (11): 1027-1036. https://doi.org/10.1093/biosci/biu146 
- $\quad$ Pascual U, Balvanera P, Díaz S, Pataki G, Roth E, Stenseke M, Watson R, Başak Dessane E, Islar M, Kelemen E, Maris V, Quaas M, Subramanian S, Wittmer H, Adlan A, Ahn S, Al-Hafedh Y, Amankwah E, Asah S, Berry P, Bilgin A, Breslow S, Bullock C, Cáceres D, Daly-Hassen H, Figueroa E, Golden C, Gómez-Baggethun E, GonzálezJiménez D, Houdet J, Keune H, Kumar R, Ma K, May P, Mead A, O'Farrell P, Pandit R, Pengue W, Pichis-Madruga R, Popa F, Preston S, Pacheco-Balanza D, Saarikoski H, Strassburg B, van den Belt M, Verma M, Wickson F, Yagi N (2017) Valuing nature's contributions to people: the IPBES approach. Current Opinion in Environmental Sustainability 26-27: 7-16. https://doi.org/10.1016/j.cosust.2016.12.006

- $\quad$ Potschin-Young M, Burkhard B, Czúcz B, Santos-Martín F (2018) Glossary of ecosystem services mapping and assessment terminology. One Ecosystem 3 https://doi.org/10.3897/oneeco.3.e27110

- Quintas-Soriano C, Garca-Llorente M, Norstrm A, Meacham M, Peterson G, Castro AJ (2019) Integrating supply and demand in ecosystem service bundles characterization across Mediterranean transformed landscapes. Landscape Ecology 34: 1619-1633.

https://doi.org/10.1007/s10980-019-00826-7

- $\quad$ Rioux J, Cimon-Morin J, Pellerin S, Alard D, Poulin M (2019) How Land Cover Spatial Resolution Affects Mapping of Urban Ecosystem Service Flows. Frontiers in Environmental Science 7 (93). https://doi.org/10.3389/fenvs.2019.00093

- Rousseau S, Deschacht N (2020) Public Awareness of Nature and the Environment During the COVID-19 Crisis. Environmental \& Resource Economics 76: 1-11. https://doi.org/10.1007/s10640-020-00445-w

- Sahle M, Yeshitela K, Saito O (2018a) Mapping the supply and demand of Enset crop to improve food security in Southern Ethiopia. Agronomy for Sustainable Development 38 (7). https://doi.org/10.1007/s13593-017-0484-0

- Sahle M, Saito O, Fürst C, Yeshitela K (2018b) Quantification and mapping of the supply of and demand for carbon storage and sequestration service in woody biomass and soil to mitigate climate change in the socio-ecological environment. The Science of the Total Environment 624: 342-354. https://doi.org/10.1016/j.scitotenv.2017.12.033

- Sauter I, Kienast F, Bolliger J, Winter B, Pazúr R (2019) Changes in demand and supply of ecosystem services under scenarios of future land use in Vorarlberg, Austria. Journal of Mountain Science 16 (12): 2793-2809. https://doi.org/10.1007/s11629-018-5124-X

- Schägner JP, Brander L, Maes J, Paracchini ML, Hartje V (2016) Mapping recreational visits and values of European National Parks by combining statistical modelling and unit value transfer. Journal for Nature Conservation 31: 71-84. https://doi.org/10.1016/j.jnc. 2016.03.001

- $\quad$ Schirpke U, Meisch C, Marsoner T, Tappeiner U (2018) Revealing spatial and temporal patterns of outdoor recreation in the European Alps and their surroundings. Ecosystem Services 31: 336-350. https://doi.org/10.1016/j.ecoser.2017.11.017

- $\quad$ Schirpke U, Egarter Vigl L, Tasser E, Tappeiner U (2019a) Analyzing Spatial Congruencies and Mismatches between Supply, Demand and Flow of Ecosystem Services and Sustainable Development. Sustainability 11 (8): 2227. https://doi.org/ 10.3390/su11082227

- Schirpke U, Candiago S, Egarter Vigl L, Jäger H, Labadini A, Marsoner T, Meisch C, Tasser E, Tappeiner U (2019b) Integrating supply, flow and demand to enhance the understanding of interactions among multiple ecosystem services. The Science of the Total Environment 651: 928-941. https://doi.org/10.1016/j.scitotenv.2018.09.235 
- $\quad$ Schröter M, Barton D, Remme R, Hein L (2014) Accounting for capacity and flow of ecosystem services: A conceptual model and a case study for Telemark, Norway. Ecological Indicators 36: 539-551. https://doi.org/10.1016/i.ecolind.2013.09.018

- Schröter M, Koellner T, Alkemade R, Arnhold S, Bagstad K, Erb K, Frank K, Kastner T, Kissinger M, Liu J, López-Hoffman L, Maes J, Marques A, Martín-López B, Meyer C, Schulp CE, Thober J, Wolff S, Bonn A (2018) Interregional flows of ecosystem services: Concepts, typology and four cases. Ecosystem Services 31: 231-241. https://doi.org/ 10.1016/j.ecoser.2018.02.003

- $\quad$ Schulp CJ, Lautenbach S, Verburg PH (2014) Quantifying and mapping ecosystem services: Demand and supply of pollination in the European Union. Ecological Indicators 36: 131-141. https://doi.org/10.1016/j.ecolind.2013.07.014

- Scott A, Carter C, Hardman M, Grayson N, Slaney T (2018) Mainstreaming ecosystem science in spatial planning practice: Exploiting a hybrid opportunity space. Land Use Policy 70: 232-246. https://doi.org/10.1016/j.landusepol.2017.10.002

- Secretariat of the Convention on Biological Diversity (2020) Global Biodiversity Outlook 5. URL: https://www.cbd.int/gbo/gbo5/publication/gbo-5-en.pdf

- Serna-Chavez HM, Schulp CJ, van Bodegom PM, Bouten W, Verburg PH, Davidson MD (2014) A quantitative framework for assessing spatial flows of ecosystem services. Ecological Indicators 39: 24-33. https://doi.org/10.1016/i.ecolind.2013.11.024

- $\quad$ Stosch KC, Quilliam RS, Bunnefeld N, Oliver DM (2017) Managing Multiple Catchment Demands for Sustainable Water Use and Ecosystem Service Provision. Water 9 (677). https://doi.org/10.3390/w9090677

- $\quad$ Syrbe R, Walz U (2012) Spatial indicators for the assessment of ecosystem services: Providing, benefiting and connecting areas and landscape metrics. Ecological Indicators 21: 80-88. https://doi.org/10.1016/j.ecolind.2012.02.013

- $\quad$ Syrbe R, Grunewald K (2017) Ecosystem service supply and demand - the challenge to balance spatial mismatches. International Journal of Biodiversity Science, Ecosystem Services \& Management 13 (2): 148-161. https://doi.org/10.1080/21513732. $\underline{2017.1407362}$

- The Economics of Ecosystems and Biodiversity (TEEB) (2010) The Economics of Ecosystems and Biodiversity: Mainstreaming the Economics of Nature: A synthesis of the approach, conclusions and recommendations of TEEB. UNEP, Geneva. [ISBN 9783981341034]

- The Natural Capital Project (NatCap) (2021) InVEST. https://naturalcapitalproject. stanford.edu/software/invest. Accessed on: 2021-1-24.

- United Nations (2019) Technical Recommendations in support of the System of Environmental-Economic Accounting 2012. Experimental Ecosystem Accounting. Series M No. 97. United Nations Publication [ISBN 978-92-1-161634-7]

- United Nations (2021) System of Environmental Economic Accounting - Ecosystem Accounting: Final Draft. URL: https://unstats.un.org/unsd/statcom/52nd-session/ documents/BG-3f-SEEA-EA Final_draft-E.pdf

- Vallecillo S, La Notte A, Zulian G, Ferrini S, Maes J (2019) Ecosystem services accounts: Valuing the actual flow of nature-based recreation from ecosystems to people. Ecological Modelling 392: 196-211. https://doi.org/10.1016/j.ecolmodel. $\underline{2018.09 .023}$

- $\quad$ van Oudenhoven AE, Petz K, Alkemade R, Hein L, de Groot R (2012) Framework for systematic indicator selection to assess effects of land management on ecosystem 
services. Ecological Indicators 21: 110-122. https://doi.org/10.1016/j.ecolind. 2012.01.012

- Venter Z, Barton D, Figari H, Nowell M (2020) Urban nature in a time of crisis: recreational use of green space increases during the COVID-19 outbreak in Oslo, Norway. Environmental Research Letters 15 (10). https://doi.org/10.1088/1748-9326/ $\underline{\text { abb396 }}$

- Verhagen W, Kukkala A, Moilanen A, van Teeffelen AA, Verburg P (2017) Use of demand for and spatial flow of ecosystem services to identify priority areas. Conservation biology : the journal of the Society for Conservation Biology 31 (4): 860-871. https://doi.org/10.1111/cobi.12872

- Villa F, Bagstad K, Voigt B, Johnson G, Portela R, Honzák M, Batker D (2014) A methodology for adaptable and robust ecosystem services assessment. PIOS ONE 9 (3). https://doi.org/10.1371/journal.pone.0091001

- Villamagna A, Angermeier P, Bennett E (2013) Capacity, pressure, demand, and flow: A conceptual framework for analyzing ecosystem service provision and delivery. Ecological Complexity 15: 114-121. https://doi.org/10.1016/j.ecocom.2013.07.004

- Vysna V, Maes J, Petersen J, La Notte A, Vallecillo S, Aizpurua N, Ivits-Wasser E, Teller A (2021) Accounting for ecosystems and their services in the European Union (INCA). Final report from phase II of the INCA project aiming to develop a pilot for an integrated system of ecosystem accounts for the EU. Publications Office of the European Union, Luxembourg. https://doi.org/10.2785/19790

- Walz U, Syrbe R, Grunewald K (2017) Where to map? In: Burkhard B, Maes J (Eds) Mapping Ecosystem Services. Pensoft Publishers, Sofia, Bulgaria, 374 pp. [ISBN 978-954-642-830-1]. https://doi.org/10.3897/ab.e12837

- Watson K, Galford G, Sonter L, Koh I, Ricketts T (2019) Effects of human demand on conservation planning for biodiversity and ecosystem services. Conservation Biology : the Journal of the Society for Conservation Biology 33 (4). https://doi.org/10.1111/cobi. $\underline{13276}$

- Wei H, Fan W, Wang X, Lu N, Dong X, Zhao Y, Ya X, Zhao Y (2017) Integrating supply and social demand in ecosystem services assessment: A review. Ecosystem Services 25: 15-27. https://doi.org/10.1016/j.ecoser.2017.03.017

- Wiggering H, Weißhuhn P, Burkhard B (2016) Agrosystem services: An additional terminology to better understand ecosystem services delivered by agriculture.

Landscape Online 49: 1-15. https://doi.org/10.3097/LO.201649

- Wolff S, Schulp CJ, Verburg PH (2015) Mapping ecosystem services demand: A review of current research and future perspectives. Ecological Indicators 55: 159-171.

https://doi.org/10.1016/j.ecolind.2015.03.016

- Wolff S, Schulp CJ, Kastner T, Verburg PH (2017) Quantifying Spatial Variation in Ecosystem Services Demand: A Global Mapping Approach. Ecological Economics 136: 14-29. https://doi.org/10.1016/j.ecolecon.2017.02.005

- Yuan M, Lo S, Chiueh P (2019) Embedding scarcity in urban water tariffs: mapping supply and demand in North Taiwan. Environmental Earth Sciences 78 (325). https://doi.org/10.1007/s12665-019-8318-9

- Zhao C, Sander H (2015) Quantifying and Mapping the Supply of and Demand for Carbon Storage and Sequestration Service from Urban Trees. PLOS ONE 10 (8): e0136392. https://doi.org/10.1371/journal.pone.0136392 
- Zhao C, Sander H, Hendrix S (2019) Wild bees and urban agriculture: assessing pollinator supply and demand across urban landscapes. Urban Ecosystems 22: 455-470. https://doi.org/10.1007/s11252-019-0826-6

- Zhao Q, Li J, Liu J, Cuan Y, Zhang C (2019) Integrating supply and demand in cultural ecosystem services assessment: a case study of Cuihua Mountain (China). Environmental Science and Pollution Research International 26: 6065-6076. https://doi.org/10.1007/s11356-018-3910-1

- Zulian G (2016) Estimap. Method factsheet. URL: https://oppla.eu/sites/default/files/ uploads/methodfactsheetestimap.pdf

\section{Supplementary materials}

Suppl. material 1: Reviewed articles. doi

Authors: Dworczyk, Claudia; Benjamin, Burkhard

Data type: Occurrences

Brief description: Detailed overview of the articles analysed and the definitions, methods and scale of analysis used.

Download file $(120.63 \mathrm{~kb})$

\section{Suppl. material 2: Ecosystem Services doi}

Authors: Dworczyk, Claudia; Burkhard, Benjamin

Data type: Occurrences

Brief description: This table shows an overview of the ecosystem services studied in the articles.

Download file $(14.08 \mathrm{~kb})$ 